\title{
RANCANGAN SISTEM APLIKASI INVENTORY PADA PONDOK PESANTREN SMP ASHHABURRATIB ALMADANI BERBASIS JAVA
}

\author{
Mei Lilis Susanti' ${ }^{1}$, Redo Abeputra Sihombing ${ }^{2}$ \\ Program Studi Informatika, Fakultas Teknik dan Ilmu Komputer, Universitas Indraprasta PGRI \\ Jalan Raya Tengah No 80, Kelurahan Gedong, Pasar Rebo, Jakarta Timur \\ meililissusanti1@gmail.com¹, redounindra@gmail.com².
}

\begin{abstract}
Abstrak
Tujuan Penelitian adaalah untuk mengetahui sistem yang berjalan dalam pencatatan pembelian dan penjualan di inventory Pondok Pesantren SMP Ashhaburratib Almadani menggunakan Java. Untuk mengetahui proses pemesanan dan pembelian di inventory Pondok Pesantren SMP Ashhaburratib Almadani berbasis Java. Aplikasi yang digunakan dapat dipahami oleh penggunanya dan membantu pengurusan dalam mengolah data administrasi. Metode pengumpulan data yang dilakukan dengan metode Waterfall yaitu metode penelitian berdasarkan observasi, wawancara, instrument penelitian, serta studi kepustakaan. Sistem ini dibuat dengan menggunakan Java Dekstop dan database MySQL. Sistem inventory ini dibuat digunakan untuk pencatatan pembelian, pencatatan penjualan, pencatatan data barang, pencatatan data pelanggan.
\end{abstract}

Kata Kunci: Perancangan Sistem Aplikasi Inventory, Java.

\begin{abstract}
The purpose of research is to know the system that is running in the recording of purchases and sales in inventory of junior high school Ashhaburratib Almadani using Java. To know the ordering process and purchase in inventory boarding schools Ashhaburratib Almadani based on Java. The applications used can be understood by the user and help management in the processing of administration data. Methods of data collection done by Waterfall method are research methods based on observation, interviews, research instruments, and literature study. This system is created using Java desktop and MySQL database. This inventory system is made for purchase recording, sales recording, data logging, customer data recording.
\end{abstract}

Keyword: Inventory Application System Design, Java.

\section{PENDAHULUAN}

Inventory Pondok Pesantren SMP Ashhaburratib Almadani, sebagai instansi yang mengurusi penjualan dan pengadaan barang yang memerlukan sistem informasi berbasis komputerisasi untuk mengelola data dan menghasilkan laporan - laporan yang akurat. Hal tersebut dilakukan karena inventory Pondok Pesantren SMP Ashhaburratib Almadani belum memanfaatkan sistem komputer secara efektif untuk melakukan kegiatan kerjanya, sedangkan pengolahan informasi dilakukan setiap saat untuk mendapatkan laporan-laporan yang dibutuhkan. Sistem informasi yang ada di inventory Pondok Pesantren SMP Ashhaburratib Almadani masih menggunakan metode manual, sehingga masih memiliki berbagai kekurangan dan kendala yang dihadapi. Harus dimulai dengan mencari data secara manual yang membutuhkan banyak waktu dan tenaga, sehingga dibutuhkan suatu sistem yang mampu membantu tugas pegawai yang bisa memberikan dampak yang signifikan untuk mengubah pekerjaan sebelumnya lamban menjadi lebih cepat.

Pada saat ini perkembangan teknologi informasi sangat cepat secara global dan tanpa adanya batasan waktu. Pekerjaan manusia yang dahulu dikerjakakan secara manual, dengan adanya teknologi komputer sehingga segala proses manual menjadi serba komputerisasi. Dalam inventory Pondok Pesantren SMP Ashhaburratib Almadani tidak lepas dari proses pembuatan laporan yang terkait dengan proses yang dijalankan dalam inventory ini. Laporan yang dihasilkan dalam koperasi ini meliputi laporan dalam hal penjualan dan pengadaan yang meliputi laporan data anggota, laporan stok barang, laporan pembelian barang, dan laporan penjualan. Berdasarkan uraian rumusan latar belakang di atas, maka dalam mengerjakan penelitian ini, peneliti berfikir untuk merancang sistem inventory pada Pondok Pesantren SMP Ashhaburratib Almadani ini menggunakan Java Netbeans dan Mysql. Oleh karena itu, untuk memberikan solusi yang terbaik kepada kepala sekolah pada khususnya, maka peneliti tertarik untuk melakukan penelitian dengan judul "Rancangan Sistem Aplikasi Inventory Pada Pondok Pesantren SMP Ashhaburratib Almadani Berbasis Java”. 
Perancangan adalah proses pengembangan spesifikasi baru berdasarkan rekomendasi hasil analisis sistem (Subhan, 2012). Sistem adalah sebuah tatanan yang terdiri atas sejumlah komponen fungsional (dengan tugas/fungsi khusus) yang saling berhubungan dan secara bersama-sama bertujuan untuk memenuhi suatu proses/pekerjaan tertentu (Kusrini, 2012). Inventory adalah sebagai suatu aktifitas lancar yang meliputi barang-barang milik perusahaan dengan maksud untuk di jual dalam suatu periode usaha normal atau persediaan barang-barang yang masih dalam pekerjaan proses produksi ataupun persediaan bahan baku atau menunggu penggunanya dalam suatu proses produksi (Asauri, 2010). Netbeans merupakan salah satu IDE (Integrated Development Environment) open source yang dikembangkan dengan bahasa pemrograman java. Netbeans mempunyai lingkupan pemrograman yang terintegraasi dalam suatu perangkat lunak yang didalamnya menyediakan pembangunan pemrograman GUI, text editor, compiler, interpreter dan suatu debugger (Westriningsih, 2012).

\section{PENELITIAN RELEVAN}

Penelitian yang berhubungan dengan perancangan sistem aplikasi inventory sudah pernah dilakukan oleh beberapa peneliti diantaranya Yuhendra. MT dkk (2013) dengan judul Perancangan Sistem Inventory Spare Parts Mobil pada CV Auto Parts Toyota Berbasis Aplikasi Java, dalam penelitiannya ini berisi tentang penanganan pengolahan data seperti pengadaan suku cadang dan penyediaan laporan. Selain itu keakuratan, ketepatan waktu, dan kerelevanan data yang dibutuhkan oleh pihak CV. Auto Parts Toyota dapat diperoleh. Perbedaan objek penelitian yang kami lakukan dimana objek penelitian antara kepala sekolah dan staff sekolah.

\section{METODE PENELITIAN}

Metode penelitian yang peneliti lakukan adalah metode penelitian dengan tahapan sebagai berikut :

1. Metode Penelitian

Metode penelitian adalah langkah dan prosedur yang akan dilakukan dalam pengumpulan data atau memecahkan permasalahan sehingga akan didapat suatu kebenaran atas data yang diperoleh. Dalam penelitian ini, peneliti menggunakan metode Waterfall. Penjelasan mengenai metode Waterfall.

2. Metode Pengumpulan Data

Metode pengumpulan data yang dilakukan oleh peneliti untuk mendapatkan data-data serta informasi untuk mendukung penyempurnaan hasil dari penelitian ini antara lain :

a. Studi Kepustakaan

Penelitian ini dilakukan dengan cara studi literatur di perpustakaan dan membaca artikel atau tulisan-tulisan yang berkaitan dengan kasus yang dibahas peneliti.

b. Studi Lapangan

1) Obeservasi

Peneliti melakukan observasi untuk melihat secara langsung sistem berjalan di Pondok Pesantren SMP Ashhaburratib Almadani. Kegiatan ini dilakukan untuk mendapatkan gambaran secara objektif sehingga dapat mengetahui apa saja yang diperlukan untuk membuat rancangan sistem aplikasi inventory.

2) Wawancara

Wawancara dilakukan untuk mendapatkan informasi guna mempermudah peneliti dalam merancang sebuah sistem aplikasi inventory di Pondok Pesantren SMP Ashhaburratib Almadani.

3) Instrument Penelitian

Infrasturktur penelitian yang digunakann untuk aplikasi yang terdiri dari perangkat lunak dan perangkat keras diantaranya :

a. Perangkat Keras (Hardware)

Adapun hardwaare yang Natebook yang digunakan adalah HP, dengan spesifikasi sebagai berikut :

1) Processor: AMD Ei-2100 APU with Radeon (TM) HD Graphics

2) Memory : 2GB

3) Harddisk : 5 GB 
b. Perangkat Lunak (Software)

Infrastruktur atau perangkat lunak yang digunakan untuk membuat penelitian ini adalah sebagai berikut :

1) Sistem Operasi Microsoft Windows 8.1. 64-bit Operating System

2) Netbeans IDE 8.0.2

3) Xampp

4) Microsoft Office Word 2013 .dan Microsoft Office Visio 2013

3. Langkah-Langkah Pengembangan Sistem

Untuk menyempurnakan hasil penelitian ini, peneliti mencoba menuliskan tahapan-tahapan yang digunakan dalam Perancangan Sistem Aplikasi Inventory Pada Pondok Pesantren SMP Ashhaburratib Almadani Berbasis Java untuk menggambarkan tahapan utama dan langkahlangkah didalam tahap tersebut dalam proses pengembangannya. Siklus hidup pengembangan sistem dapat dibagi dalam tahapan sebagai berikut :

a. Persiapan Data

Dalam tahap ini peneliti melakukan pengumpulan kebutuhan seluruh elemen sistem seperti data-data yang digunakan sehingga elemen-elemen itu dapat menunjang dalam pengembangan aplikasi sistem pemesanan.

b. Merancang Sistem (Design System)

Perancangan sistem menggunakan metode Diagram Aliran Data (DAD). Sedangkan desain interface dibuat dalam bentuk jendela halaman java dengan beberapa form seperti from login, form menu utama, form barang, form pelanggan, form pembelian, form penjualan, form persediaan. Dalam form-form tersebut memiliki berbagai macam proses yaitu penyimpanan data, pengeditan keterangan data, dan penhapusan data serta laporan-laporan persediaan barang yang dibutuhkan.Desain program yang dilakukan ialah dengan menggunakan aplikasi Netbeans8.2 untuk membuat tampilan halaman dekstop dengan bahasa pemrograman java script.

c. Pengkodean (Coding)

Bahasa pemrograman yang digunakan adalah java untuk desain form barang masuk dan barang keluar yang akan dirancang dan menggunakan database Mysql sebagai penampungan data-datanya. Sedangkan coding metode yang digunakan dalam kontrol persdiaan barang ialah metode Lost In Frist Out (LIFO) dan Average perpetual akan diterapkan untuk laporan laba/rugi persediaan barang.

d. Pengujian Sistem

Sebelum sisem aplikasi digunakan, maka harus dilakukan pengujian terlebih dahulu. Pengujian dilakukan untuk memastikan apakah semua fungsi sistem aplikasi bekerja dengan baik. Rangkaian pengujian ini sangat penting dilakukan untuk menjamin kualitas software, dan juga menjadi peninjau terakhir terhadap spesifikasi, desain dan pengkodean dari sistem yang telah ada atau sistem yang berjalan. Selain itu, peneliti dapat mengetahui kekurangankekurangan aplikasi sistem kontrol informasi yang akan digunakan.

e. Implementasi

Tahapan hasil dari sistem yang sudah dirancang dan berjalan sesuai rencana dan melakukan perbaikan jika memang sistem yang telah dibuat perlu untuk diperbaiki. Sistem yang dirancang diharapkan mampu mengatasi masalah yang ada dalam proses pembelian dan penjualan barang pada Inventory Pondok Pesantren SMP Ashhaburratib AlMadani Depok.

f. Pemeliharaan

Tahap akhir dalam metode waterfall. Perangkat lunak yang sudah jadi, dijalankan serta dilakukan pemeliharaan. Pemeliharaan termasuk dalam memperbaiki kesalahan yang tidak ditemukan dalam langkah sebelumnya. Perbaikan implementasi unit sistem dan peningkatan jasa sistem sebagai kebutuhan.

\section{HASIL PEMBAHASAN}

Dalam aturan bisnis didalamnya menjelaskan tentang kebijakan-kebijakan pada sistem yang dibahas antara lain: 
1. Pendataan Barang

a. Pada proses ini yang berhak menggunakan atau masukan data adalah Kepala Sekolah.

b. Sebelum Kepala Sekolah melakukan penginputan setiap data akan di periksa dan dibuat sebuah form, form tersebut berisikan data barang yang nantinya akan di input oleh Kepala Sekolah.

c. Proses selanjutnya adalah Kepala Sekolah melakukan penginputan data. Proses penginputan ini akan menghasilkan database db_barang.

2. Pendataan Penjualan

Pada proses ini kasir memasukan data pada sistem, data ini berisikan beberapa informasi barang terjual, dan akan menghasilkan database db_penjualan.

3. Laporan

Proses ini akan menjelaskan pembuatan laporan secara keseluruhan kepada Kepala Sekolah untuk mengetahui hasil penjualan.

Berikut ini merupakan penggambaran tentang Perancangan sistem aplikasi inventory yang diusulkan pada pondok Pondok Pesantren Ashhaburratib Almadani secara keseluruhan:

\section{Diagram Konteks}

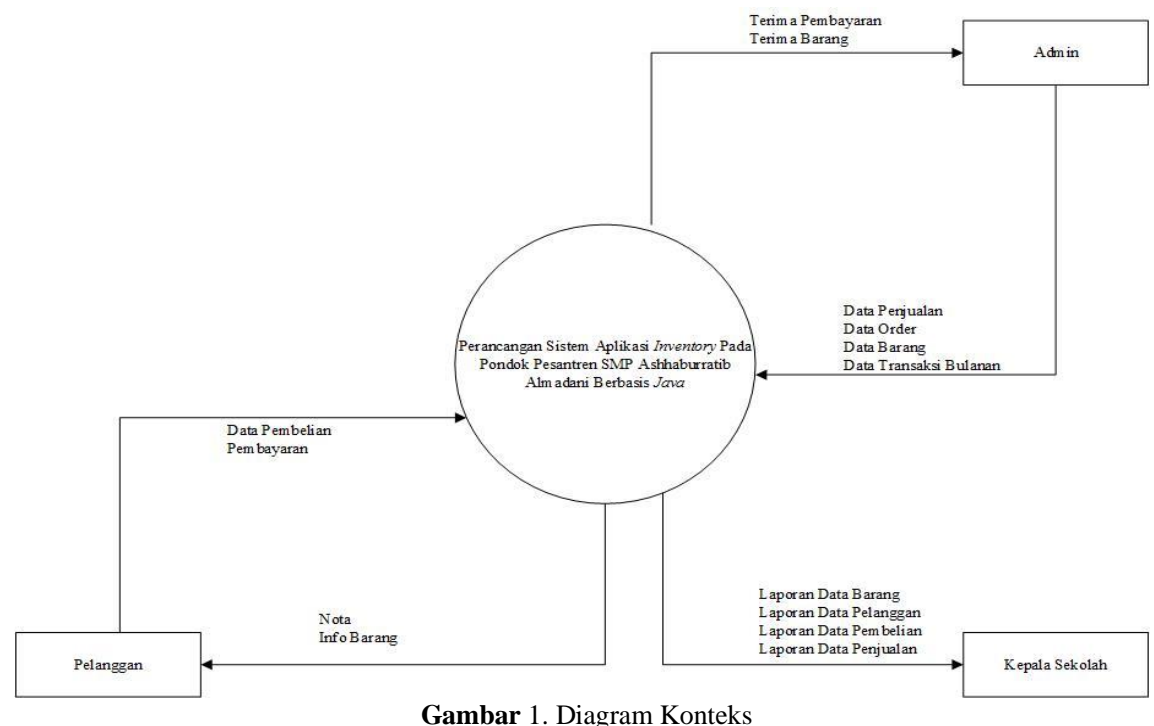

\section{Diagram ERD (Entity Relationship Diagram)}

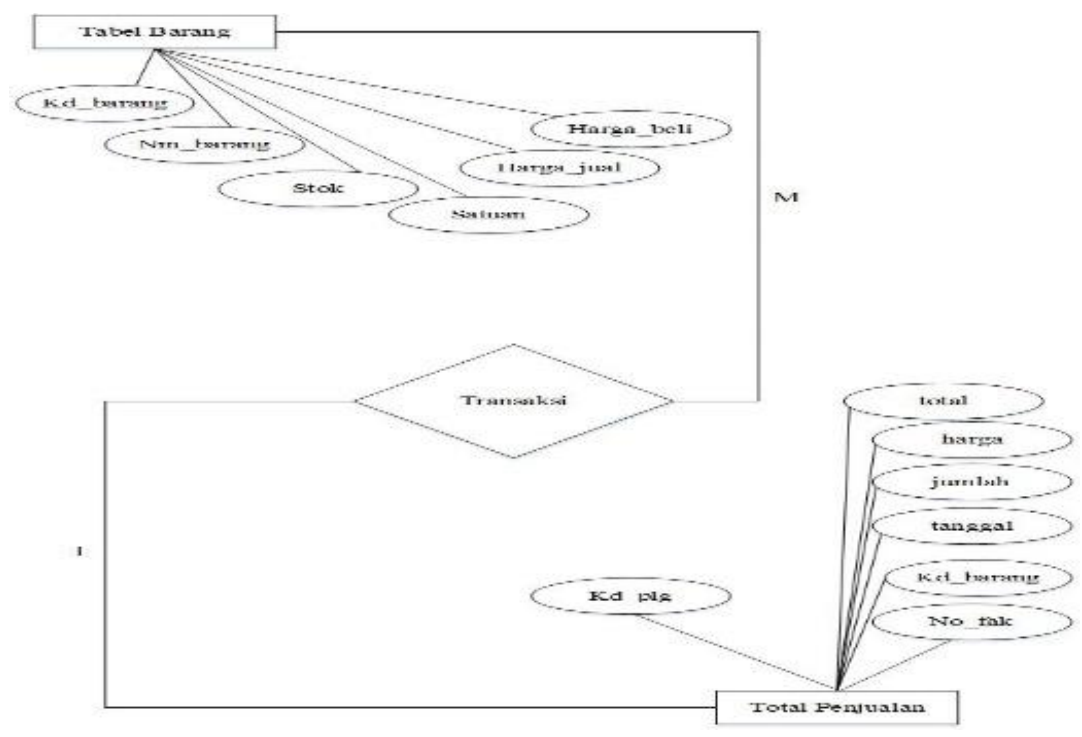

Gambar 2. Diagram ERD (Entity Relationship Diagram) 
Selanjutnya peneliti membuat aplikasi dengan menggunakan java NetBeans berbasis dekstop dan database mysql. Berikut ini adalah tampilan dari Perancangan Sistem Aplikasi Inventory Pada Pondok Pesantren Ashhaburratib Almadani Berbasis Java:

\section{Tampilan Layar}

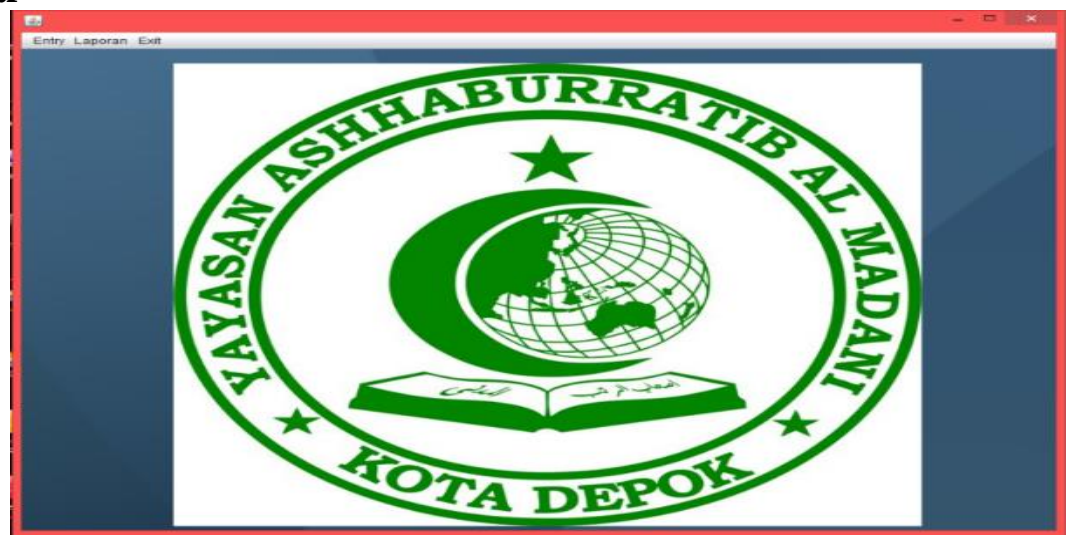

Gambar 3. Tampilan Halaman Utama

Tampilan ini adalah merupakan tampilan utama pada aplikasi Inventory. Dalam tampilan ini terdapat menu-menu yang berfungsi untuk mengakses form yang ada pada aplikasi Inventory.

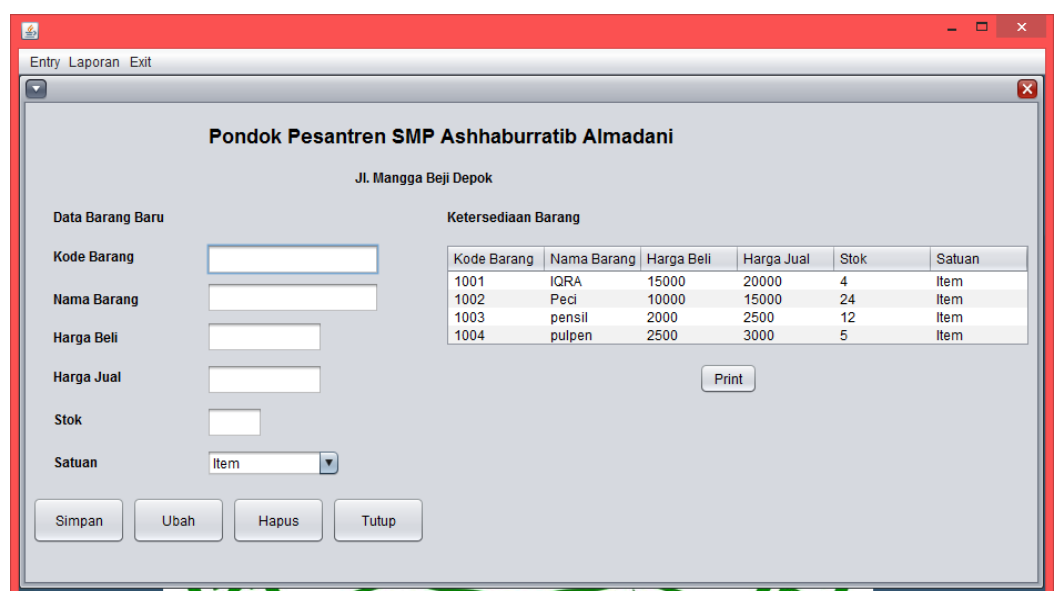

Gambar 4. Tampilan Layar Form Data Barang

Gambar 4 merupakan tampilan form data barang baru yang berfungsi untuk mendata data barang pada saat diterima dari distributor. Pada form ini Admin dapat menyimpan, mengubah, dan menghapus dari database.

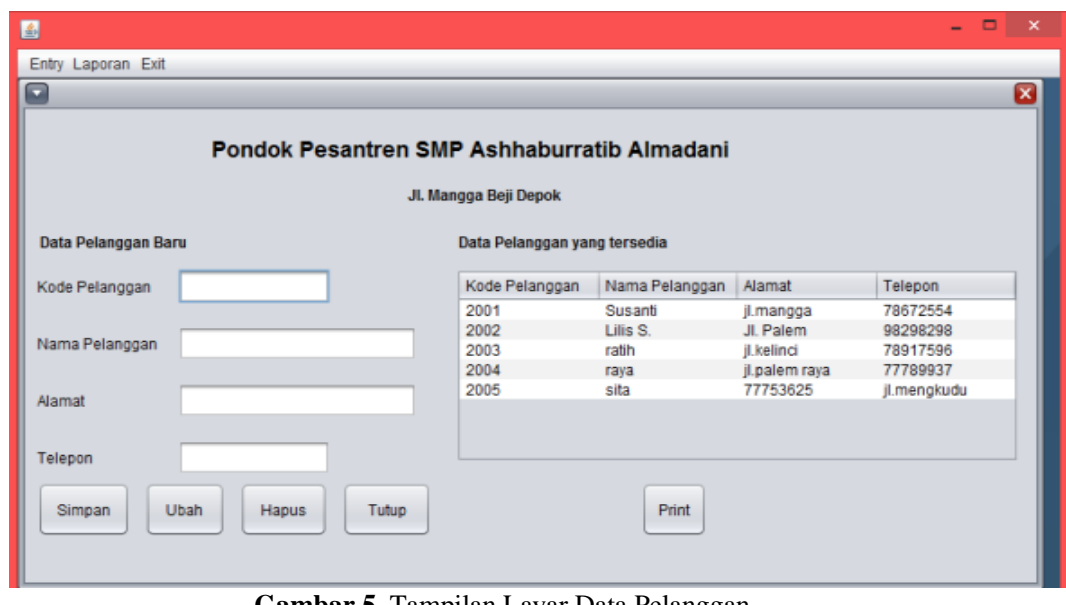

Gambar 5. Tampilan Layar Data Pelanggan 
Tampilan ini merupakan tampilan form data pelanggan yang berfungsi untuk memasukan data pelanggan. Pada form ini Admin dapat menyimpan, mengubah, dan menghapus data pelanggan.

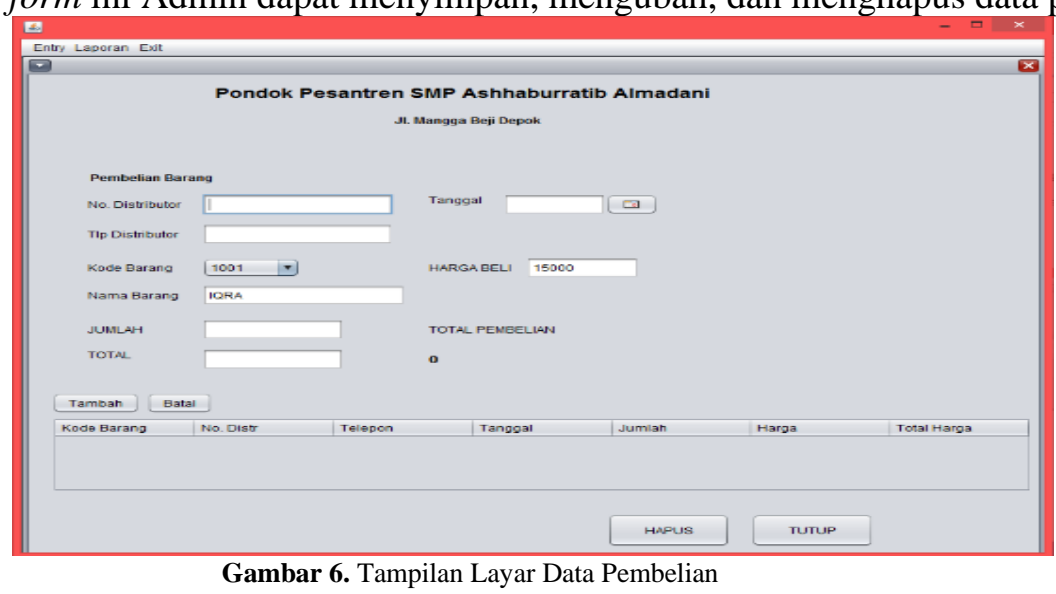

Tampilan ini merupakan tampilan form data pembelian barang yang berfungsi untuk melihat data pembelian barang yang dikirim oleh distributor.

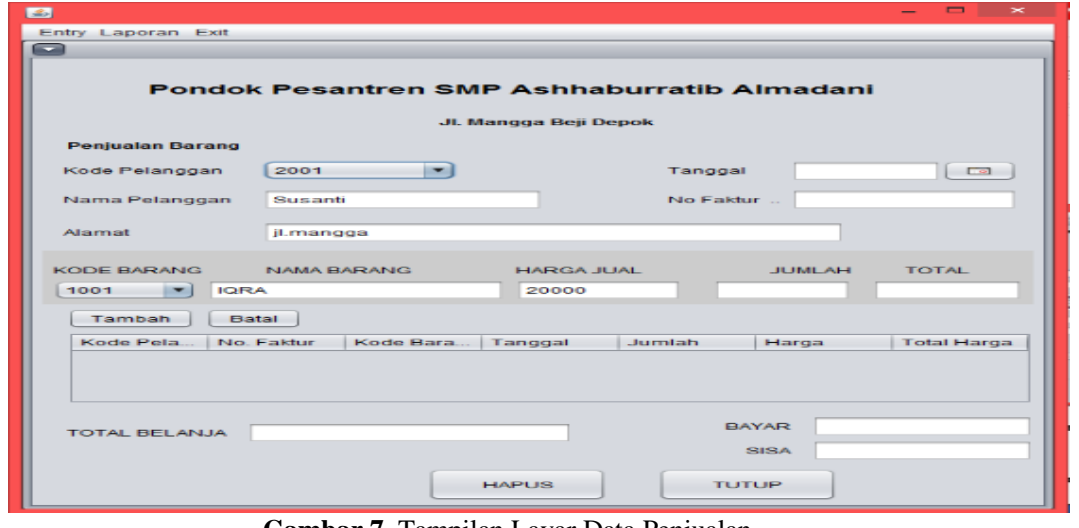

Gambar 7. Tampilan Layar Data Penjualan

Pada Gambar 7 Admin dapat menambah dan mengubah database. Tampilan ini merupakan tampilan form penjualan barang yang berfungsi untuk memasukan jumlah transaksi pembelian yang dilakukan oleh pelanggan. Pada form ini Admin dapat menambah dan membatalkan pembelian barang.

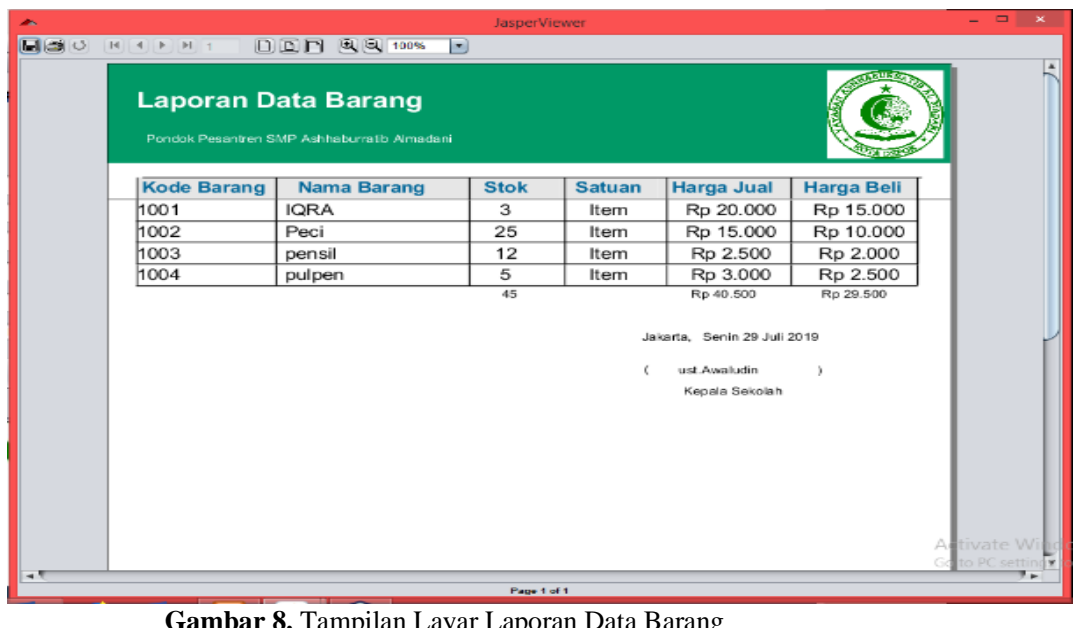

Tampilan ini merupakan tampilan layar laporan data barang yang berfungsi untuk menampilkan data barang yang telah masuk di dalam sistem inventory. Pada form ini Admin akan menampilkan laporan data barang masuk yang tersimpan di sistem inventory. 


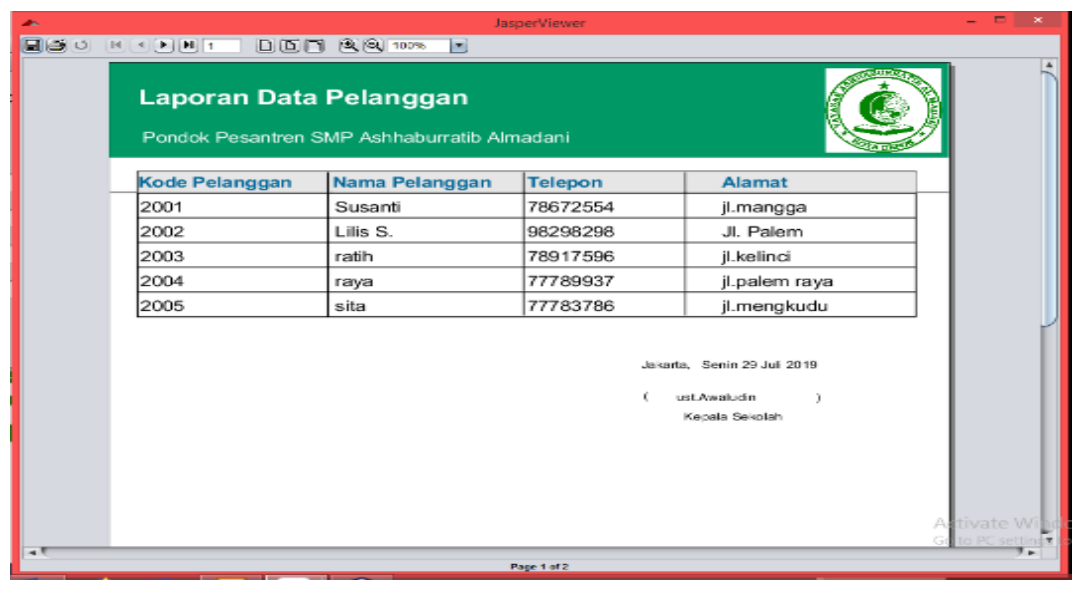

Gambar 9. Tampilan Layar Laporan Data Pelanggan

Gambar 9 merupakan tampilan layar laporan data pelangga yang berfungsi untuk menampilkan data pelanggan di dalam sistem inventory. Pada form ini Admin akan menampilkan laporan data pelanggan yang tersimpan di sistem inventory.

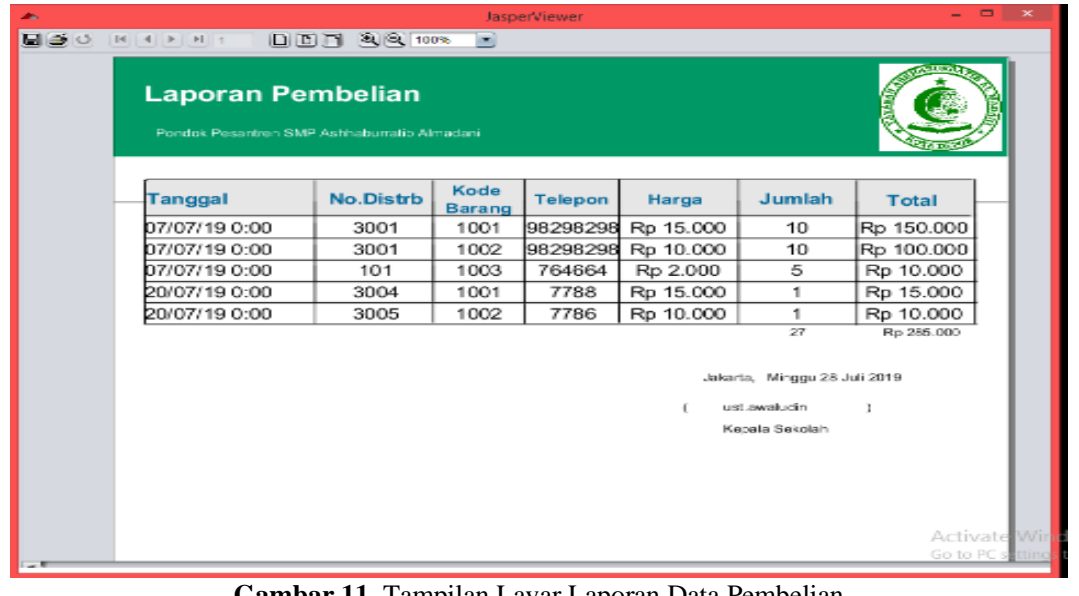

Gambar 11. Tampilan Layar Laporan Data Pembelian

Tampilan ini merupakan tampilan layar laporan data pembelian yang berfungsi untuk menampilkan data yang telah masuk di dalam sistem inventory. Pada form ini Admin akan menampilkan data laporan pembelian barang masuk yang tersimpan di sistem inventory.

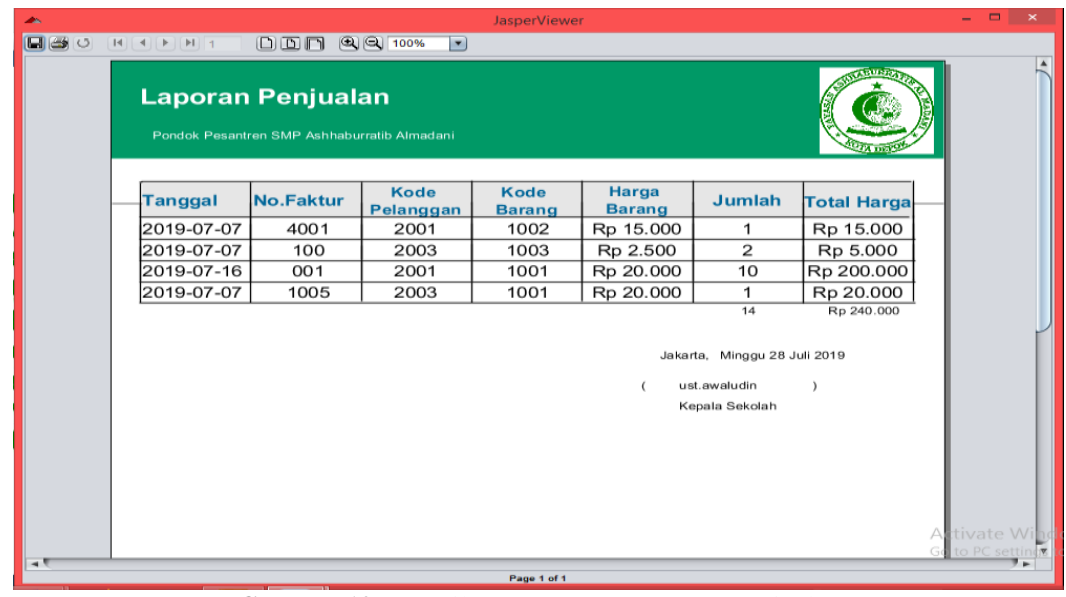

Gambar 12. Tampilan Layar Laporan Data Penjualan 
Tampilan ini merupakan tampilan layar data penjualan yang berfungsi untuk menampilkan data yang telah keluar di dalam sistem inventory. Pada form ini Admin akan menampilan data laporan barang keluar yang tersimpan di dalam sistem inventory.

\section{SIMPULAN}

Berdasarkan analisa yang telah di uraikan dari bab sebelumnya, maka dapat disimpulkan perihal Perancangan Sistem Aplikasi Inventory Pada Pondok Pesantren Ashhaburratib Almadani Berbasis Java sebagai berikut :

1. Setelah adanya sistem berjalan yang mampu mengelola data penjualan dan pembelian sehingga dapat mengefektifkan dan mengefisienkan kinerja proses transaksi pada inventory.

2. Proses pemesanan pembelian barang dari distributor menjadi lebih mudah karena dalam proses pengecekan stok barang di inventory menjadi lebih mudah.

3. Proses rekap data, laporan-laporan penjualan dan pembelian barang menjadi lebih efektif dan sefisien karena sudah tersimpan di dalam database yang ke mungkinan kecil terjadinya kehilangan atau kerusakan dokumen.

\section{DAFTAR PUSTAKA}

Agusvianto, H. (2017). Sistem Informasi Inventori Gudang Untuk Mengontrol Persediaan Barang Pada Gudang Studi Kasus: PT.Alaisys Sidoarjo. Journal of Information Engineering and Educational Technology. https://doi.org/10.26740/jieet.v1n1.p40-46

Assauri, S. (2011). Manajemen Pemasaran Dasar Konsep dan Strategi. In PT RajaGrafindo Persada, Jakarta. https://doi.org/10.1109/ACC.2007.4282338

Kusrini. (2012). Sistem Pakar. Yogyakarta :Andi Offisit.

Rendi Poerwanta. (2013). Perancangan Sistem Inventory Spare Parts Mobil Pada Cv . Auto Parts Toyota Berbasis Aplikasi Java. Jurnal TEKNOIF.

Subhan, M. (2012). Analisa PErancangan Sistem. In Analisa perancangan sistem.

Westriningsih. (2012). Panduan Aplikatif \& Solusi (PAS) Membangun Aplikasi Bisnis dengan Netbeans 7. Yogyakarta: Andi. 